\title{
Whiplash-like facet joint loading initiates glutamatergic responses in the DRG and spinal cord associated with behavioral hypersensitivity
}

\author{
Ling Dong ${ }^{\mathrm{a}}$, Julia C. Quindlen ${ }^{\mathrm{a}}$, Daniel E. Lipschutz ${ }^{\mathrm{a}}$, and Beth A. Winkelstein ${ }^{\mathrm{a}, \mathrm{b},{ }^{*}}$ \\ aDepartment of Bioengineering, University of Pennsylvania, Philadelphia, PA 19104, USA \\ ${ }^{b}$ Department of Neurosurgery, University of Pennsylvania, Philadelphia, PA 19104, USA
}

\begin{abstract}
The cervical facet joint and its capsule are a common source of neck pain from whiplash. Mechanical hyperalgesia elicited by painful facet joint distraction is associated with spinal neuronal hyperexcitability that can be induced by transmitter/receptor systems that potentiate the synaptic activation of neurons. This study investigated the temporal response of a glutamate receptor and transporters in the dorsal root ganglia (DRG) and spinal cord. Bilateral C6/C7 facet joint distractions were imposed in the rat either to produce behavioral sensitivity or without inducing any sensitivity. Neuronal metabotropic glutamate receptor-5 (mGluR5) and protein kinase C-epsilon (PKCe) expression in the DRG and spinal cord were evaluated on days 1 and 7. Spinal expression of a glutamate transporter, excitatory amino acid carrier 1 (EAAC1), was also quantified at both time points. Painful distraction produced immediate behavioral hypersensitivity that was sustained for 7 days. Increased expression of mGluR5 and PKCe in the DRG was not evident until day 7 and only following painful distraction; this increase was observed in smalldiameter neurons. Only painful facet joint distraction produced a significant increase $(p<0.001)$ in neuronal mGluR5 over time, and this increase also was significantly elevated ( $\mathrm{p} \leq 0.05$ ) over responses in the other groups at day 7. However, there were no differences in spinal PKC $\varepsilon$ expression on either day or between groups. Spinal EAAC1 expression was significantly increased $(\mathrm{p}<0.03)$ only in the nonpainful groups on day 7 . Results from this study suggest spinal glutamatergic plasticity is selectively modulated in association with facet-mediated pain.
\end{abstract}

\section{Keywords}

mechanical hyperalgesia; glutamate receptor; glutamate transporter; protein kinase C; facet; spinal cord

\section{Introduction}

Whiplash-related injury produces persistent neck pain that affects nearly $20 \%$ of the general population (Croft et al., 2001). One of the primary causes of chronic pain from whiplash is over-stretching of the capsular ligament (Deng et al., 2000; Luan et al., 2000; Panjabi et al.,

\footnotetext{
(C) 2012 Elsevier B.V. All rights reserved.

"Correspondence: Beth A. Winkelstein, PhD, Dept. of Bioengineering, University of Pennsylvania, 240 Skirkanich Hall, 210 S. 33rd Street, Philadelphia, PA 19104-6321, 215-573-4589 (phone), 215-573-2071 (fax), winkelst@ seas.upenn.edu.

Publisher's Disclaimer: This is a PDF file of an unedited manuscript that has been accepted for publication. As a service to our customers we are providing this early version of the manuscript. The manuscript will undergo copyediting, typesetting, and review of the resulting proof before it is published in its final citable form. Please note that during the production process errors may be discovered which could affect the content, and all legal disclaimers that apply to the journal pertain.
} 
1998; Pearson et al., 2004; Sundararajan et al., 2004; Yoganandan et al., 1998, 2002). The afferents that innervate the facet joint can be activated in response to mechanical stimulation of the joint (Avramov et al., 1992; Cavanaugh et al., 1989; Khalsa et al., 1996; Pickar and McLain, 1995). Electrophysiological studies demonstrate that tensile loading of the cervical facet joint capsule induces activation in the dorsal rootlets innervating the joint and sustained spinal neuronal hyperexcitability (Chen et al., 2006; Lu et al., 2005; Quinn et al., 2010). Despite this evidence of immediate and long term neuronal activity, the mechanism of how painful joint stretch activates neuronal nociceptive activity is still unknown.

Neuronal hyperexcitability in association with joint pain is initiated by transmitter/receptor systems that modulate synaptic activity with glutamate as one of the key neurotransmitters in the spinal cord (Hutchinson et al., 2011; Schaible et al., 2002; Valtschanoff et al., 1994). Glutamate application increases neuronal excitation in a primate model of knee joint arthritis (Dougherty et al., 1992). Additionally, glutamate in the superficial dorsal horn of the spinal cord increases within 24 hours after the induction of painful arthritis (Dougherty et al., 1993; Sluka and Westlund 1993). Although studies of joint pain collectively suggest a role for glutamate in the development and persistence of mechanically initiated facet-mediated joint pain, the temporal response of the spinal glutamatergic system, such as glutamate receptors and transporters, has not been defined in joint or whiplash-related pain.

The metabotropic glutamate receptors (mGluRs) have been shown to induce sensitivity when given intrathecally or by intraplantar administration (Bhave et al., 2001; Dogrul et al., 2000; Hama, 2003; Karim et al., 2001). In particular, spinal mGluR5 administration increases the excitability of primary afferents in a rat model of inflammatory pain (Pitcher et al., 2007). Following activation of mGluR5, intracellular calcium release is believed to be regulated by PKC (Jong et al., 2009; Xu et al., 2007). However, PKC-epsilon (PKCe) has been implicated in several pathological pain states (Ahlgren and Levine, 1994; Amadesi et al., 2006; Dina et al., 2000; Ferreira et al., 2005; Khasar et al., 1999; Souza et al., 2002). Significant increases in the expression of both mGluR5 and PKCe have been observed in the DRG at day 7 in a model of painful facet joint injury in the adolescent rat (Weisshaar et al., 2010). Although these studies strongly suggest the contributions of mGluR5 and its downstream effects to nociceptive transmission, it remains to be seen whether changes in mGluR5 and PKCe in the DRG and spinal cord occur following painful facet joint injury.

Since excessive extracellular glutamate levels can enhance synaptic transmission and contribute to cell death, glutamate uptake by the excitatory amino acid transporters (EAATs) is important in regulating the extracellular concentrations at synapses (Dingledine and McBain, 1999; Rimaniol et al., 2001; Zhang et al., 2009). Of the five subtypes of membrane glutamate transporters, only EAAT1-EAAT3 are found in the spinal cord (Chaudhry et al., 1995; Kanai et al., 1993; Rothstein et al., 1996). EAAT3 (also known as excitatory amino acid carrier 1 (EAAC1)), is expressed primarily on neurons (Ginsberg et al., 1995; He et al., 2000). EAAC1 have been shown to be down-regulated in the spinal cord after painful peripheral nerve injury (Sung et al., 2003; Wang et al., 2006). Despite evidence suggesting the pathological function of this neuronal glutamate transporter after peripheral nerve injury, their temporal contributions to facet-mediated pain are not known.

Our group has previously demonstrated that painful facet joint distraction mimicking whiplash injury up-regulates spinal mGluR5 and decreases EAAC1 expression correlated with the severity of injury and behavioral hypersensitivity (Dong and Winkelstein, 2010). However, that work did not evaluate the effect of the joint loading itself or assess the cellular glutamatergic response, including the temporal neuronal expression of the glutamate receptor, $\mathrm{PKC} \varepsilon$, and glutamate transporters. The objective of this study is to investigate the temporal response of the glutamatergic system in the DRG and spinal cord after joint 
distractions that separately do and do not produce pain. As such, dynamic facet capsule stretch was applied using joint magnitudes known to and not to produce behavioral hypersensitivity (Dong et al., 2008, 2011). Both mGluR5 and PKC $\varepsilon$ expression were evaluated in nociceptive neurons of the DRG as well as in the spinal cord at early (day 1) and later (day 7) time points. Given that glutamate transporters are responsible for maintaining a basal level of glutamate in the synaptic cleft (Dingledine and McBain, 1999; Vera-Portocarrero et al., 2002), EAAC1 was also quantified in the spinal dorsal horn at days 1 and 7 in the context of behavioral hypersensitivity.

\section{Results}

\subsection{Injury Severity \& Behavioral Outcomes}

Both the joint distraction and capsule strain magnitudes describing the loading severity were different in the painful and nonpainful conditions. The mean vertebral distraction for the painful group $(0.44 \pm 0.10 \mathrm{~mm})$ was significantly greater $(\mathrm{p}<0.001)$ than the distraction for the nonpainful group $(0.17 \pm 0.06 \mathrm{~mm})$ (Table 1$)$. Similarly, the painful group $(0.34 \pm 0.07$ $\mathrm{mm})$ also sustained a significantly higher $(\mathrm{p}<0.0001)$ average capsular distraction relative to the nonpainful group $(0.12 \pm 0.05 \mathrm{~mm})$. The maximum tensile strain in the joint capsule after painful distraction $(18.16 \pm 11.59 \%)$ was significantly greater $(\mathrm{p}=0.03)$ than that strain after the nonpainful distraction $(9.08 \pm 6.17 \%)$. Further, the maximum principal strain that the capsule underwent in the painful group $(19.43 \pm 11.43 \%)$ was also significantly higher $(\mathrm{p}=0.0006)$ than that for the nonpainful group $(6.29 \pm 6.17 \%)$ (Table 1$)$. There was no difference in any of the mechanical injury metrics between each of the injury groups that were used for tissue harvests at day 1 and those at day 7 for either type of distraction.

Mechanical hyperalgesia also exhibited graded responses after the different distraction magnitudes. There was no significant difference in the baseline unoperated withdrawal threshold measured for any of the groups (Figure 1). Response thresholds remained high for sham at all time points and were not significantly different from their corresponding baseline (unoperated) responses (Figure 1A). Overall, the response threshold patterns elicited in the painful group were significantly lower $(\mathrm{p}<0.02)$ than both the nonpainful and sham responses, corresponding to an increased behavioral sensitivity. In particular, the painful group exhibited an immediate and significant $(\mathrm{p}<0.001)$ reduction in response threshold compared to its baseline that persisted over the duration of the post-operative period (Figure 1A). The response thresholds for the nonpainful group were not significantly different from sham or their baseline responses at any time, and were significantly $(\mathrm{p}<0.001)$ higher than those for the painful group on all days (Figure 1A). Similarly, there was no difference in paw withdrawal thresholds at baseline for the group of rats in which tissue was harvested at day 1 (Figure 1B). Also, the response threshold for the painful group was significantly decreased for both the nonpainful $(\mathrm{p}<0.002)$ and $\operatorname{sham}(\mathrm{p}<0.001)$ at day 1 (Figure 1B). Further, the paw withdrawal thresholds elicited by each of the 3 groups of rats for tissue harvest at day 7 were not different from day 1.

\section{2. mGluR5 \& PKC in the DRG}

Increased expression of mGluR5 in the DRG was specific only to the painful loading and was not evident until day 7 (Figure 2). All groups (painful, nonpainful, sham) exhibited comparable mGluR5 expression that was not different from normal un-operated level at day 1. In contrast, neuronal mGluR5 expression at day 7 after painful distraction was significantly increased ( $\mathrm{p} \leq 0.012$ ) over nonpainful distraction and sham and normal controls (Figure 2). The neuronal mGluR5 expression for all groups remained below 10\% at day 1, with the painful group increasing significantly $(\mathrm{p}<0.001)$ to $26 \pm 5 \%$ at day 7 and the nonpainful and sham groups remaining at $13 \pm 3 \%$ and $12 \pm 2 \%$, respectively (Figure 2I). 
Similarly, there was no significant difference in the expression of mGluR5 in the small- and medium-sized neurons at day 1 in any of the groups. However, by day 7 there was a significant increase $(\mathrm{p}=0.013)$ in the percentage of small neurons that was expressing mGluR5 after painful distraction compared to sham; this was not the case in the mediumdiameter neurons (Figure 2J).

Immunoreactivity for PKC $\varepsilon$ exhibited the same trend as mGluR5 expression in the DRG. Neuronal PKC $\varepsilon$ expression in the DRG also was not changed from normal levels in the nonpainful and sham groups at either time point (Figure 2). Further, neuronal PKCe expression after painful distraction was comparable to the nonpainful, sham and normal levels at day 1 . The sham responses at days 1 and 7 exhibited similar levels of expression, which were not different from normal. Only the painful distraction produced a significant increase ( $\mathrm{p}<0.001)$ in neuronal PKCe expression at day 7 compared to day 1 (Figure $2 \mathrm{~K}$ ). Moreover, at day 7 after painful loading, PKC $\varepsilon$ expression was more than doubled and was significantly increased $(\mathrm{p}<0.001)$ over both of the other groups (Figure $2 \mathrm{~K}$ ). PKC $\varepsilon$ expression in both small- and medium-sized neurons was not different for any group at day 1 ; yet, the percent of both the small- and medium-diameter neurons expressing PKC $\varepsilon$ was elevated after painful distraction at day 7 (Figure 2L). However, this increase was only significant $(\mathrm{p}<0.03)$ when compared to sham.

\subsection{Spinal mGluR5, PKC \& EAAC1}

The expression of each of mGluR5 and PKCe in the spinal cord after painful, nonpainful, and sham distraction displayed different trends relative to normal expression than those observed in the DRG. Total mGluR5 expression at day 1 was not different from normal for any of the groups, with no significant difference detected after the painful and nonpainful distractions or the sham procedures (Figure 3I). Interestingly, the total expression of mGluR5 for all groups at day 7 increased significantly ( $\mathrm{p} \leq 0.001)$ compared to day 1 and were all elevated over normal levels at day 7 ( $\mathrm{p} \leq 0.001$ ) (Figure 3). Neuronal mGluR5 expression was only changed at day 7 after painful distraction (Figure 3). While neuronal mGluR5 expression at day 7 following nonpainful and sham procedures remained at normal and day 1 levels, neuronal mGluR5 after painful distraction was significantly higher ( $\mathrm{p} \leq$ 0.05 ) than all groups at day 7 and exhibited a significant $(p<0.001)$ four-fold increase from expression levels induced by painful distraction at day 1 (Figure 3J).

Similarly, there was no difference between groups in the total expression of PKC $\varepsilon$ in the spinal cord at either time point or relative to normal levels (Figure 4). Even though the neuronal PKCe expression following both nonpainful and sham procedures was lower than that of the painful distraction at day 1, this difference was not significant (Figure 4J). There was a significant increase $(\mathrm{p}<0.001)$ in the neuronal PKC $\varepsilon$ expression induced in all groups over time, but there was no difference between painful, nonpainful and sham at day 7 (Figure 4).

The neuronal glutamate transporter (EAAC1) in the spinal cord exhibited differential changes between the different joint loading conditions and time points (Figure 5). Specifically, EAAC1 expression at day 1 was not different between any groups (Figure 5). Interestingly, at day 7, spinal EAAC1 expression was different between the painful and nonpainful conditions (Figure 5). Although spinal EAAC1 expression did not change over time for the painful group, it did increase significantly from $6.8 \pm 0.5 \%$ and $1.8 \pm 1.4 \%$ to $18.9 \pm 3.7 \%$ and $20.8 \pm 3.6 \%$ for the nonpainful $(\mathrm{p}=0.02)$ and $\operatorname{sham}(\mathrm{p}=0.001)$ groups, respectively (Figure 5). These increases were significant $(\mathrm{p}<0.03)$ compared to the EAAC1 expression at day 7 after a painful distraction. 


\section{Discussion}

These findings suggest that sustained behavioral hypersensitivity produced by a dynamic facet joint distraction induces delayed modifications in the glutamatergic system in both the DRG and spinal cord. In particular, increases in mGluR5 and PKCe expression in the DRG were only evident at day 7 in response to joint loading that also produced pain (Figures 1 and 2), suggesting that the glutamate receptor and its second messenger may work cooperatively to contribute to the maintenance, rather than the development, of behavioral hypersensitivity. However, in the spinal cord, neuronal mGluR5 expression was only elevated at day 7 after a painful distraction, despite similar increases in the total mGluR5 expression in all groups at that time point (Figure 3). This finding suggests that the changes in spinal mGluR5 at day 7 may not be related to pain but to joint loading and manipulation of the spinal tissues that was evident in all groups, and that specific nociceptive-specific mechanisms are initiated prior to day 7 to selectively mediate the neuronal responses in the spinal cord. Increases in mGluR5 can facilitate over-stimulation of glutamate by binding to its receptors, leading to neuronal apoptosis (Caruso et al., 2004; Lea and Faden, 2003). The lack of early modification in spinal mGluR5 expression at day 1 in this study in the presence of behavioral hypersensitivity at that time point after the painful distraction (Figures 1 and 2) suggests that pain in this model is initiated by other pathways that may not involve mGluR5. In addition to being a downstream messenger of mGluR5, PKC has also been suggested to stimulate and sensitize nociceptors by increasing calcium influx and inhibiting potassium currents (Alkon et al., 1986; Deriemer et al., 1985; Leng et al., 1996; Schepelmann et al., 1993). However, spinal neuronal expression of PKCe was observed after painful distraction only at day 7 and was evident in all groups regardless of the presence or absence of pain (Figure 3). Taken together, these findings suggest that the onset of behavioral hypersensitivity in this model is likely mediated by other regulatory factors in the spinal cord. Indeed, facet-mediated pain has been shown to induce neuronal hyperexcitability in the spinal cord as early as 1 day after painful distraction supporting such a notion (Crosby and Winkelstein, 2011). However, the exact mechanisms by which mGluR5 modifications are induced in this pain model are still unclear.

Expression of mGluR5 and PKCe in the DRG were similar over time (Figure 2), suggesting that they may be modulated by the same initial stimulus. Since PKC $\varepsilon$ can regulate G-protein coupled receptors, such as mGluR5 (Conn and Pin, 1997; Schoepp et al., 1999), there may be a potential role of PKCe-dependent mGluR5 signaling in hyperalgesia following this painful joint injury. In fact, $\mathrm{PKC} \varepsilon$ activation is required for mGluR5-mediated development of mechanical hypersensitivity in a rat model of chronic muscular hyperalgesia (Lee and Ro, 2007). The current study demonstrates that the modifications in mGluR5 and PKCe expression in the DRG were exhibited in the small-diameter neurons (Figure 2), which is consistent with a previous report of a significant increase in the number of small DRG neurons that express mGluR5 and PKC $\varepsilon$ after painful joint injury in an adolescent model (Weisshaar et al., 2010). In another study of painful spinal nerve ligation, mGluR5 was also up-regulated in small-diameter nociceptive A-fibers in the DRG (Hudson et al., 2002). Furthermore, mGluR5 activation on the central presynaptic terminals of nociceptive neurons has been shown to induce mechanical hyperalgesia in rats (Kim et al., 2009). Conversely, inhibition of PKC $\varepsilon$ attenuates glutamate release in isolated spinal cord preparations and reduces formalin-induced nociception in vivo (Sweitzer et al., 2004). Also, application of an mGluR5 antagonist can effectively reduce hyperalgesia in both inflammatory and neuropathic pain (Fisher et al., 2002; Walker et al., 2001). Together with the current findings, it is likely that both mGluR5 and PKC $\varepsilon$ enhance nociceptive transmission and contribute to behavioral hypersensitivity after facet joint injury. 
In the spinal cord, neuronal mGluR5 expression was increased only at day 7 in the painful case (Figure 3). This supports previous reports of a delayed onset increase between 1-8 weeks in rat rubrospinal neurons (Wang and Tseng, 2004). Because group I metabotropic glutamate receptors can induce excitation and increase intracellular calcium levels, both of which may be harmful to neuronal survival (Pin and Bockaert, 1995), the increased expression of mGluR5 observed in this study in association with behavioral hypersensitivity at day 7, further substantiates the role of mGluR5 in the maintenance of facet joint pain. The sustained upregulation of mGluR5 in the spinal cord also has been shown to activate the NMDA receptor via PKC dependent pathways (Byrnes et al., 2009; Karim et al., 2001; Mills et al., 2001; Xu et al., 2007). However, since expression of PKCe was not modified at day 7 in the spinal cord in the current study (Figure 4), the specific mechanisms by which spinal mGluR5 contributes to pain in this model still remain unclear. It is likely that this glutamate receptor works cooperatively with other downstream messengers, such as calmodulin and ERK to maintain behavioral sensitivity (Choi et al., 2011). Nonetheless, the selective modification of neuronal mGluR5 in the spinal cord after a painful distraction suggests it to have a potent association with mechanisms regulating facet pain. Future studies investigating the ionotropic receptor in conjunction with spinal mGluR5 are necessary to elucidate the temporal contributions of the mGluR5-triggered cascades leading to the persistence of pain in this pain model.

In association with modulation of neuronal spinal mGluR5 at day 7 (Figure 3), this study also demonstrates dysregulation of spinal EAAC1 expression at day 7 only after painful facet joint distraction (Figure 5). Interestingly, in this case, the EAAC1 expression increased at day 7 in the conditions that did not produce pain and remained unchanged in the painful distraction case, suggesting that injury condition may suppress the normal expression of EAAC1 in association with pain production. EAATs are thought to be rapidly upregulated in the spinal cord in response to high concentrations of extracellular glutamate that can be due to injury or perceived injury in the CNS (Liu et al., 1991; McAdoo et al., 1999; VeraPortocarrero et al., 2002). Chronic painful sciatic nerve constriction can induce elevated EAAC1 expression for up to 4 days after the initial injury, but this elevation is also reversed and even decreased by day 7 (Sung et al., 2003). Similarly, spinal EAAC1 expression has also been shown to be down-regulated at day 7 after a painful peripheral nerve injury (Shashidharan et al., 1997), indicating decreased transport of extracellular glutamate at day 7 post-injury. This notion is further supported by the fact that EAAC1 expression is unchanged in primary astrocyte cultures despite lowered glutamate uptake, in response to oxidative stress (Miralles et al., 2001). Taken together with the upregulation of spinal mGluR5 that is observed at day 7 only in the painful case (Figure 3), it is possible that the primary afferents from the facet joint that synapse in the spinal cord may be sensitized through the activation of mGluR5 due to the lack of neuronal glutamate uptake by EAAC1, contributing to the sustained sensitivity that is observed in this study (Figures 3 and 5). This is consistent with previous findings suggesting that the cellular stress response is activated in neurons that innervate the capsule following painful joint loading (Dong et al., 2008). Although immunohistochemical data show that EAAC1 is localized to the superficial laminae, it still remains to be seen whether the localization is specific to the nociceptive afferents. Such information may help identify if neuronal glutamate transporters have a role in abnormal firing of nociceptive afferents in the spinal cord following facet joint injury.

Results from this study show that both mGluR5 and PKCe increase in the DRG after painful distraction at day 7 and that neuronal mGluR5 and EAAC1 expression in the spinal cord also increase at the same time point after painful joint injury (Figures 2, 3 and 5). In addition to being a second messenger for mGluR5, activation of PKC can also increase the mechanosensitivity of neurons through insertion of ion channels into the cell membrane (Di Castro et al., 2006). The inhibition of PKCe also can directly reduce glutamate release in the 
spinal cord (Sweitzer et al., 2004). Therefore, it may be possible that neuronal excitability is increased by these mechanisms. By including the nonpainful distraction case in the current study, it is possible to distinguish those responses that are specifically related to painful loading of this joint. For example, the findings in the DRG are consistent with those previously reported in an adolescent facet pain model (Weisshaar et al., 2010), but now provide context that the increased PKC $\varepsilon$ and mGluR5 noted in that work is indeed specific to a painful condition and not simply a result of the mechanical manipulation of the joint. In contrast, the spinal neuronal PKCe expression is not differentially modulated in any of the injury conditions, suggesting it likely does not contribute to the maintenance of pain in this model. The finding here that total mGluR5 expression in the spinal cord was not different between any group at day 7 (Figure 3I) is not consistent with our previous study using this same injury model (Dong and Winkelstein, 2010). However, in that work Western blot assay was performed using the entire spinal cord which prevented the specific assessment of responses localized to the superficial dorsal horn. Given that mGluR5 immunoreactivity has been noted in the deeper laminae of the spinal cord and our model also exhibits activation of neurons and glia in those spinal laminae (Alvarez et al., 2000; Lee et al., 2004a; Quinn et al., 2010), it is possible that mGluR5 expression may be selectively increased in other regions of the spinal cord that was not detected in the current study.

Collectively, these results suggest that the symptoms following painful distraction may not be initiated by aspects of the glutamatergic system but may be sustained through them. However, this study did not specifically probe glutamate levels in the spinal cord, and that information is requisite to draw any direct conclusions about the contribution of glutamate to neuronal hyperexcitability and pain that are observed after this painful facet joint distraction (Crosby and Winkelstein, 2011; Quinn et al., 2010). Further, this study only investigated two discrete time points after joint injury (day 1, day 7) and used C6 DRGs and C7 spinal cord samples. Given that the protein levels for each of the molecules (mGluR5, PKCe, EAAC1) probed in both the DRG and spinal cord all exhibit some modification over time after either type of joint distraction (Figures 2-5), it is necessary to also investigate additional time points between days 1 and 7 to fully capture the role of glutamatergicinduced sensitization in facet-mediated pain. Further, additional assays of the upper and lower segments of the spinal cord may provide a more complete picture of these relative responses and the extent of their modifications.

\section{Conclusions}

This study finds modifications in the glutamatergic system throughout the nervous system that exhibit temporal variability for whiplash-related facet joint injury that produces pain in the adult rat. In particular, neuronal mGluR5 and PKC $\varepsilon$ in the DRG were unchanged at day 1, but both were significantly elevated after painful distraction at day 7 (Figure 2), suggesting that they may have a role in the maintenance of mechanical hyperalgesia after painful joint loading (Figure 1). This study further demonstrates a delayed increase in neuronal mGluR5 expression in the spinal cord at day 7 only in the painful case, despite an increase in total mGluR5 regardless of the presence or absence of pain (Figure 3). In contrast, spinal EAAC1 was increased only in the nonpainful conditions (Figure 5). These results suggest the possibility that spinal plasticity occurs via the glutamate receptor and transporter regulatory systems after painful facet capsule distraction (Quinn et al., 2010), since decreased glutamate transporter and increased mGluR5 may both over-stimulate nociceptive neurons and decrease their thresholds to mechanical stimulation ( $\mathrm{Li}$ and Neugebauer, 2003). Future work utilizing specific inhibitors of these receptors and transporters is necessary to fully understand the mechanisms of the glutamate receptor and transporter to the induction and maintenance of pain. Nonetheless, this work suggests that reversing abnormal neuronal sensitization by blocking mGluR5 and PKC $\varepsilon$ and enhancing 
EAAC1 expression could attenuate or abolish facet-mediated neck pain following whiplashlike joint loading.

\section{Experimental Procedures}

\subsection{Surgical Procedures}

Male Holtzman rats weighing 375-450 grams were housed under USDA- and AAALACcompliant conditions with a 12-12 hour light-dark cycle and free access to food and water. All experimental procedures were approved by the Institutional Animal Care and Use Committee and carried out under the guidelines of the Committee for Research and Ethical Issues of the International Association for the Study of Pain (Zimmermann, 1983).

Surgical procedures were performed under isoflurane inhalation anesthesia ( $4 \%$ for induction, $2.5 \%$ for maintenance). Using previously described methods, rats were placed in a prone position and a skin incision was made to expose and isolate the bilateral $\mathrm{C} 6 / \mathrm{C} 7$ facet joints (Lee et al., 2004b, 2008; Dong et al., 2008; Dong and Winkelstein, 2010). A customized loading device was used to impose a controlled distraction across the bilateral C6/C7 facet joints (Dong and Winkelstein, 2010). During joint distraction, the right facet joint was imaged throughout the loading period using a high-speed camera (Vision Research, Inc., Wayne, NJ; 50 pixels/mm resolution) attached to the surgical microscope.

Facet joint distraction was imposed at magnitudes of either $0.5 \mathrm{~mm}$ (painful, $\mathrm{n}=12$ ) or 0.2 $\mathrm{mm}$ (nonpainful, $\mathrm{n}=12$ ), since those distractions have been shown to separately produce and not produce behavioral sensitivity, respectively (Dong et al., 2008, 2011; Dong and Winkelstein 2010; Lee et al., 2004a; 2006). The C6 vertebra was translated rostrally at a rate of $15 \mathrm{~mm} / \mathrm{s}$ corresponding to an estimated tensile strain rate of 500\%/sec across the facet capsule, simulating the strain rate of capsule stretch in whiplash injury (Panjabi et al., 1998; Stemper et al., 2005; Sundararajan et al., 2004; Yoganandan et al., 1998). The C6/C7 facet joint was then unloaded at the same rate. Sham procedures were also performed using a separate group of rats ( sham, $\mathrm{n}=12$ ), in which the bilateral $\mathrm{C} 6 / \mathrm{C} 7$ facet joints and capsules were exposed and attached to the microforceps of the loading device. After all surgical procedures, the surgical space was rinsed with Betadine ${ }^{\circledR}$ (Purdue Pharma, Stamford, CT) and the wound was closed using 3-0 polyester suture and surgical staples. Rats were allowed to recover in room air and monitored throughout the postoperative period.

In order to quantify the severity of loading to the facet joint and capsular ligament, polystyrene microspheres (Spherotech, Inc., Libertyville, IL; diameter $=0.17 \pm 0.01 \mathrm{~mm}$ ) were placed on the surfaces of the lamina of $\mathrm{C} 6$ and $\mathrm{C} 7$ vertebrae and the $\mathrm{C} 6 / \mathrm{C} 7$ right facet capsule to enable their motion tracking during joint distraction. Image tracking software (Image J, Bethesda, MD) was used to locate the centroids of each marker during the distraction. Vertebral distraction was defined as the relative displacement of the centroid of the C6 marker to that of the $\mathrm{C} 7$ marker. The average capsular distraction was defined as the average resultant displacement of the markers on the rostral edge of the capsule relative to that on the caudal edge (Dong and Winkelstein, 2010; Lee et al., 2004b). In addition, the maximum tensile strain in the direction of joint loading (rostral-caudal) and the peak maximum principal strain were also calculated using the LS-DYNA software (Livermore Software Technology Corp., Livermore, CA) (Dong and Winkelstein, 2010; Quinn et al., 2007). To determine whether the two joint distractions imposed different kinematics for the $\mathrm{C} 6 / \mathrm{C} 7$ capsule, the tensile and maximum principal strains were separately compared between painful and nonpainful groups, using a Student's t-test. All statistical tests were performed using SYSTAT (SYSTAT Software Inc., Richmond, CA), with significance at $\mathrm{p}<0.05$ for all tests. 


\subsection{Behavioral Assessments}

Behavioral sensitivity was assessed in each rat ( $\mathrm{n}=12$ each surgical group) by measuring bilateral mechanical hyperalgesia in the forepaws, using a modified version of Chaplan's updown method (Chaplan et al., 1994; Lee et al., 2008; Hubbard and Winkelstein, 2005). Mechanical hyperalgesia was measured on postoperative days 1, 3, 5, and 7, using von Frey filaments of logarithmically-increasing strengths from $0.6 \mathrm{~g}$ to $26 \mathrm{~g}(0.6,1.4,2,4,6,8,10$, 15, 26g) (Stoelting Co., Wood Dale, IL). Rats were also assessed prior to surgery to provide baseline measurements as a control, unoperated response for each rat. Each filament was applied five times before moving on to the next higher filament with a stronger strength. The response threshold was recorded as the first filament to elicit a positive response if the next filament in the series also evoked a positive response. However, if the next filament failed to elicit a positive response, testing was continued using successively larger filaments until two consecutive filaments both elicited a positive response. A positive response was indicated by emphatic lifting of the paw, often accompanied by licking. Each testing session consisted of three rounds, separated by at least 10 minutes of a recovery period. Testing was performed on each forepaw separately, and the average of all rounds in a session was taken as the response threshold for each paw. The data from each of the right and left forepaws were combined to an average for each rat. A repeated measures ANOVA, with post hoc Bonferonni correction was used to compare temporal hyperalgesia between painful, nonpainful, and sham groups.

\subsection{Immunuhistochemistry of DRG and Spinal Cord}

DRGs at the C6 level were harvested after behavioral testing on day 1 ( $n=6$ each surgery group) and on day 7 ( $\mathrm{n}=6$ each surgery group) to assess the temporal neuronal mGluR5 and $\mathrm{PKC} \varepsilon$ expression. Matched DRGs were also harvested from naïve un-operated rats $(\mathrm{n}=2)$, and were included in all analyses as controls. On the day of tissue harvest, rats were anesthetized with sodium pentobarbital $(65 \mathrm{mg} / \mathrm{kg})$ and transcardially perfused with $250 \mathrm{ml}$ of PBS followed by $250 \mathrm{ml}$ of $4 \%$ paraformaldehyde. DRG samples were then post-fixed in $4 \%$ paraformaldehyde for 1 hour at room temperature and transferred to 50\% ethanol overnight, dehydrated in a graded ethanol series, and embedded in paraffin. Transverse sections ( $16 \mu \mathrm{m}, 3-6$ per rat) were collected at $160 \mu \mathrm{m}$ through each DRG. Sections were mounted onto APES-coated slides, deparaffinized and rehydrated. Antigen retrieval was performed by incubating the slides in the target retrieval solution (Dako, Carpinteria, CA) for 30 minutes in a $95^{\circ} \mathrm{C}$ water bath. Sections were then blocked in 5\% goat serum (Vector; Burlingame, CA) containing $0.03 \%$ triton X-100 for 2 hours at room temperature, followed by overnight incubation in either rabbit anti-mGluR5 (1:1000; Millipore, Billerica, MA) or rabbit anti-PKCe (1:1000; Santa Cruz Biotechnology; Santa Cruz, CA). Each antibody was also co-labeled with a neuronal marker, mouse anti-MAP2 (1:200; Covance; Emeryville, $\mathrm{CA})$, at $4^{\circ} \mathrm{C}$. The next day, slides were washed three times with PBS and treated with AlexaFluor 488 goat anti-rabbit and Alexa-Fluor 546 goat anti-mouse secondary antibodies (1:1000; Invitrogen, Carlsbad, CA) for 2 hours. Slides were washed thoroughly three times with PBS, quick-rinsed with $\mathrm{diH}_{2} \mathrm{O}$, and cover-slipped using Fluoro-Gel (EMS; Hatfield, PA).

Each DRG section was imaged at 40X magnification on a Carl Zeiss LSM 510 microscope (Carl Zeiss LLC, Thornwood, NY) equipped with Argon, HeNe and Coherent Chameleon fs-pulsed NIR lasers. Two images were taken in each section such that each image had a similar number ( $\sim 10)$ and size (small- and medium-diameter) of neurons to ensure unbiased sampling. Neuronal expression of mGluR5 and PKCe in the DRG was quantified using two methods. In the first method, densitometry was performed to quantify the amount of colocalization of mGluR5 or PKCe immunoreactivity with neurons, normalized by the total area of neurons (Akay et al., 2011; Dong et al., 2008). Co-localization was taken as the 
location of double-positive signals for either mGluR5 or PKCe together with MAP2, where positive signals were defined as pixel intensities that were higher than background activity in normal naïve tissue (Rothman and Winkelstein, 2007, 2010; Hubbard and Winkelstein, 2008). While this densitometry method provides a measurement of how much mGluR5 and PKC $\varepsilon$ is expressed within neurons, it does not differentiate changes specific to small- and/or medium-diameter neurons, which are nociceptive and mechanoreceptive, respectively. A second approach evaluated the percent of small- and medium-sized neurons that were mGluR5- and PKCe-immunoreactive by counting the number of each neuron type in each section from each DRG sample (Weisshaar et al., 2010). In each image, all neurons were measured for diameter by taking an average of the length and width of the cell. Only neurons with a visible nucleus were included; an average of $10 \pm 4$ neurons was included for each image. Specifically, neurons were classified as small- $(4-20 \mu \mathrm{m})$ and medium- (22-40 $\mu \mathrm{m}$ ) sized based on their measured diameter (Weisshaar et al., 2010). A neuron was determined to be positively-labeled for mGluR5 or PKCe by comparing the amount of fluorescence to the levels of background and in control tissues. The percentage of small- and medium-sized neurons that was also mGluR5- and PKCe-immunoreactive was then quantified. The amount of neuronal expression and the percent of positive mGluR5 and $\mathrm{PKC} \varepsilon$ expression in small- and medium-diameter neurons were separately compared between groups by one-way ANOVA. A two-way ANOVA was also used to test for differences in each protein over time.

Spinal cord tissue was also collected at the $\mathrm{C} 7$ cervical level at days 1 ( $\mathrm{n}=6$ each surgery group) and 7 ( $\mathrm{n}=6$ each surgery group) to evaluate the temporal expression of mGluR5, its second messenger (PKCe), and the neuronal transporter EAAC1 in the dorsal horn in context of joint loading severity. After transcardiac perfusion, tissue was post-fixed for 1518 hours followed by cryopreservation in $30 \%$ sucrose/PBS and stored for 3 days at $4^{\circ} \mathrm{C}$. Spinal cord tissue was then freeze-mounted with Histoprep (Fisher Diagnostic; Fair Lawn, $\mathrm{NJ})$. Thin cryosections $(16 \mu \mathrm{m}, 6$ sections per rat) were mounted onto APES-slides for staining. Slides were incubated in primary antibodies to mGluR5 (1:1000; Millipore; Billerica, MA) or PKCe (1:1000; Santa Cruz Biotechnology; Santa Cruz, CA), and colabeled with MAP2 (1:200; Covance; Emeryville, CA); slides were also incubated with EAAC1 (1:200; Santa Cruz Biotechnology, Santa Cruz, CA) overnight at $4^{\circ} \mathrm{C}$. Secondary incubation was performed using goat anti-rabbit Alexa 488 and goat anti-mouse Alexa 546 (1:500 each; Invitrogen; Carlsbad, CA) before cover-slipping using Fluoro-Gel (EMS; Hatfield, PA).

The spinal cord samples were imaged at $10 \mathrm{X}$ as described above. Images were cropped to include the superficial dorsal horn $(900 \times 300$ pixels) (Mense and Prabhakar, 1986; Todd, 2002). Total expression for each marker was measured as the percentage of pixels above the expression levels detected in the normal un-operated spinal cord tissues (Abbadie et al., 1996; Rothman and Winkelstein, 2007, 2010; Lee et al., 2004a). Neuronal mGluR5 and $\mathrm{PKC} \varepsilon$ expression were each calculated by quantifying the amount of positive staining that co-localized with MAP2, using the same methods as described above. Expression of mGluR5, PKCe, and EAAC1 between groups (painful, nonpainful, sham, normal) was compared using a one-way ANOVA with Bonferroni post-hoc test for each protein separately for each day of assessment. Separate two-way ANOVAs were also used to compare the differences for each protein over time.

\section{Acknowledgments}

This work was funded in part by grants from the National Institutes of Health/National Institute of Arthritis, Musculoskeletal and Skin Diseases (\#AR056288) and the Catharine D. Sharpe Foundation. 


\section{References}

Abbadie C, Brown JL, Mantyh PW, Basbaum AI. Spinal cord substance P receptor immunoreactivity increases in both inflammatory and nerve injury models of persistent pain. Neuroscience. 1996; 70:201-209. [PubMed: 8848125]

Ahlgren SC, Levine JD. Protein kinase C inhibitors decrease hyperalgesia and C-fiber hyperexcitability in the streptozotocin-diabetic rat. J Neurophysiol. 1994; 72:684-692. [PubMed: 7983528]

Akay C, Lindl KA, Shyam N, Nabet B, Goenage-Vazguez Y, Ruzbarsky J, Wang Y, Kolson DL, Jordan-Sciutto KL. Activation status of integrated stress response pathways in neurons and astrocytes of HAND cortex. Neuropathol Appl Neurogiol. 2011 in press. 10.1111/j.1365-2990

Alkon DL, Kubota M, Neary JT, Naito S, Coulter D, Rasmussen H. C-kinase activation prolongs $\mathrm{Ca}^{2+}$-dependent inactivation of $\mathrm{K}^{+}$currents. Biochem Biophys Res Commun. 1986; 134:12451253. [PubMed: 3790201]

Alvarez FJ, Villalba RM, Carr PA, Grandes P, Somohano PM. Differential distribution of metabotropic glutamate receptors 1a, 1b, and 5 in the rat spinal cord. J Comp Neurol. 2000; 422:464-487. [PubMed: 10861520]

Amadesi S, Cottrell GS, Divino L, Chapman K, Grady EF, Bautista F, Karanjia R, Barajas-Lopez C, Vanner S, Vergnolle N, Bunnett NW. Protease-activated receptor 2 sensitizes TRPV1 by protein kinase Cepsilon- and A-dependent mechanisms in rats and mice. J Physiol. 2006; 575:555-571. [PubMed: 16793902]

Avramov AI, Cavanaugh JM, Ozaktay CA, Getchell TV, King AI. The effects of controlled mechanical loading on group-II, III, and IV afferent units from the lumbar facet joint and surrounding tissue. An in vitro study. J Bone Joint Surg Am. 1992; 74:1464-1471. [PubMed: 1469006]

Bhave G, Karim F, Carlton SM, Gereau RW IV. Peripheral group I metabotropic glutamate receptors modulate nociception in mice. Nat Neurosci. 2001; 4:417-423. [PubMed: 11276233]

Byrnes KR, Stoica B, Loane DJ, Riccio A, Davis MI, Faden AI. Metabotropic glutamate receptor 5 activation inhibits microglial associated inflammation and neurotoxicity. Glia. 2009; 57:550-560. [PubMed: 18816644]

Caruso C, Bottino MC, Pampillo M, Pisera D, Jaita G, Duvilanski B, Seilicovich A, Lasaga M. Glutamate induces apoptosis in anterior pituitary cells through group II metabotropic glutamate receptor activation. Endocrinology. 2004; 145:4677-4684. [PubMed: 15208212]

Cavanaugh JM, el-Bohy A, Hardy WN, Getchell TV, Getchell ML, King AI. Sensory innervation of soft tissues of the lumbar spine in the rat. J Orthop Res. 1989; 7:378-388. [PubMed: 2522984]

Chaplan SR, Bach FW, Pogrel JW, Chung JM, Yaksh TL. Quantitative assessment of tactile allodynia in the rat paw. J Neurosci Methods. 1994; 53:55-63. [PubMed: 7990513]

Chaudhry FA, Lehre KP, van Lookeren Campagne M, Ottersen OP, Danbolt NC, Storm-Mathisen J. Glutamate transporters in glial plasma membranes: highly differentiated localizations revealed by quantitative ultrastructural immunocytochemistry. Neuron. 1995; 15:711-720. [PubMed: 7546749]

Chen C, Lu Y, Kallakuri S, Patwardhan A, Cavanaugh JM. Distribution of A-delta and C-fiber receptors in the cervical facet joint capsule and their response to stretch. J Bone Joint Surg Am. 2006; 88:1807-1816. [PubMed: 16882906]

Choi KY, Chang K, Pickel JM, Badger JD II, Roche KW. Expression of the metabotropic glutamate receptor 5 (mGluR5) induces melanoma in transgenic mice. Proc Natl Acad Sci USA. 2011; 108:15219-15224. [PubMed: 21896768]

Conn PJ, Pin JP. Pharmacology and functions of metabotropic glutamate receptors. Annu Rev Pharmacol Toxicol. 1997; 37:205-237. [PubMed: 9131252]

Croft PR, Lewis M, Papageorgiou AC, Thomas E, Jayson MI, Macfarlane GJ, Silman AJ. Risk factors for neck pain: a longitudinal study in the general population. Pain. 2001; 93:317-25. [PubMed: 11514090]

Crosby, ND.; Winkelstein, BA. Spinal neuronal hyperexcitability is induced within 1 day of a painful facet joint injury. BMES Annual Mtg, \#Thurs-1-5-D; Hartford, CT. 2011. 
Deng B, Begeman P, Yang K, Tashman S, King A. Kinematics of human cadaver cervical spine during low speed rear-end impacts. Stapp Car Crash J. 2000; 44:171-188. [PubMed: 17458726]

Deriemer SA, Strong JA, Albert KA, Greengard P, Kaczmarek LK. Enhancement of calcium current in Aplysia neurons by phorbol ester and protein kinase C. Nature. 1985; 313:313-316. [PubMed: 2578617]

Di Castro A, Drew LJ, Wood JN, Cesare P. Modulation of sensory neuron mechanotransduction by PKC- and nerve growth factor-dependent pathways. Proc Natl Acad Sci USA. 2006; 103:46994704. [PubMed: 16537426]

Dina OA, Barletta J, Chen X, Mutero A, Martin A, Messing RO, Levine JD. Key role for the epsilon isoform of protein kinase $C$ in painful alcoholic neuropathy in the rat. J Neurosci. 2000; 20:86148619. [PubMed: 11069970]

Dingledine, R.; McBain, CJ. Glutamate and aspartate. In: Siegel, GJ.; Agranoff, BW.; Albers, RW.; Fisher, SK.; Uhler, MD., editors. Basic Neurochemistry: Molecular, Cellular and Medical Aspects. Lippincott-Raven; Philadelphia: 1999. p. 315-334.

Dogrul A, Ossipov MH, Lai J, Malan TP Jr, Porreca F. Peripheral and spinal antihyperalgesic activity of SIB-1757, a metabotropic glutamate receptor (mGLUR(5)) antagonist, in experimental neuropathic pain in rats. Neurosci Lett. 2000; 292:115-118. [PubMed: 10998562]

Dong L, Guarino BB, Jordan-Sciutto KL, Winkelstein BA. Activating transcription factor 4, a mediator of the integrated stress response, is increased in the dorsal root ganglia following painful facet joint distraction. Neuroscience. 2011; 193:377-386. [PubMed: 21821103]

Dong L, Odeleye AO, Jordan-Sciutto KL, Winkelsten BA. Painful facet injury induces neuronal stress activation in the DRG: implications for cellular mechanisms of pain. Neurosci Lett. 2008; 443:90 94. [PubMed: 18675314]

Dong L, Winkelstein BA. Simulated whiplash modulates expression of the glutamatergic system in the spinal cord suggesting spinal plasticity is associated with painful dynamic cervical facet loading. $\mathrm{J}$ Neurotrauma. 2010; 27:163-174. [PubMed: 19772459]

Dougherty PM, Palecek J, Paleckova V, Sorkin LS, Willis WD. The role of NMDA and non-NMDA excitatory amino acid receptors in the excitation of primate spinothalamic tract neurons by mechanical, chemical, thermal, and electrical stimuli. J Neurosci. 1992; 12:3025-3041. [PubMed: 1353793]

Ferreira J, Trichês KM, Medeiros R, Calixto JB. Mechanisms involved in the nociception produced by peripheral protein kinase C activation in mice. Pain. 2005; 117:171-181. [PubMed: 16099101]

Fisher K, Lefebvre C, Coderre TJ. Antinociceptive effects following intrathecal pretreatment with selective metabotropic glutamate receptor compounds in a rat model of neuropathic pain. Pharmacol Biochem Behav. 2002; 73:411-418. [PubMed: 12117596]

Ginsberg SD, Martin LJ, Rothstein JD. Regional deafferentation down-regulates subtypes of glutamate transporter proteins. J Neurochem. 1995; 65:2800-2803. [PubMed: 7595581]

Hama AT. Acute activation of the spinal cord metabotropic glutamate subtype-5 receptor leads to cold hypersensitivity in the rat. Neuropharmacol. 2003; 44:423-430.

He Y, Janssen WG, Rothstein JD, Morrison JH. Differential synaptic localization of the glutamate transporter EAAC1 and glutamate receptor subunit GluR2 in the rat hippocampus. J Comp Neurol. 2000; 418:255-269. [PubMed: 10701825]

Hubbard RD, Winkelstein BA. Transient cervical nerve root compression in the rat induces bilateral forepaw allodynia and spinal glial activation: Mechanical factors in painful neck injuries. Spine. 2005; 301:1924-1932. [PubMed: 16135981]

Hubbard RD, Winkelstein BA. Dorsal root compression produces myelinated axonal degeneration near the biomechanical thresholds for mechanical behavioral hypersensitivity. Exp Neurol. 2008; 212:482-489. [PubMed: 18572166]

Hudson LJ, Bevan S, McNair K, Gentry C, Fox A, Kuhn R, Winter J. Metabotropic glutamate receptor 5 upregulation in A-fibers after spinal nerve injury: 2-methyl-6-(phenylethynyl)-pyridine (MPEP) reverses the induced thermal hyperalgesia. J Neurosci. 2002; 22:2660-2668. [PubMed: 11923431]

Hutchinson MR, Shavit Y, Grace PM, Rice KC, Maier SF, Watkins LR. Exploring the neuroimmunopharmacology of opioids: an integrative review of mechanisms of central immune 
signaling and their implications for opioid analgesia. Pharmacol Rev. 2011; 63:772-810. [PubMed: 21752874]

Jong YJ, Kumar V, O’Malley KL. Intracellular metabotropic glutamate receptor 5 (mGluR5) activates signaling cascades distinct from cell surface counterparts. J Biol Chem. 2009; 284:35827-35838. [PubMed: 19840937]

Kanai Y, Smith CP, Hediger MA. A new family of neurotransmitter transporters: the high-affinity glutamate transporters. FASEB J. 1993; 7:1450-1459. [PubMed: 7903261]

Karim F, Wang CC, Gereau RW. Metabotropic glutamate receptor subtypes 1 and 5 are activators of extracellular signal-regulated kinase signaling required for inflammatory pain in mice. J Neurosci. 2001; 21:3771-3779. [PubMed: 11356865]

Khalsa PS, Hoffman AH, Grigg P. Mechanical states encoded by stretch-sensitive neurons in feline joint capsule. J Neurophysiol. 1996; 76:175-187. [PubMed: 8836217]

Khasar SG, Lin YH, Martin A, Dadgar J, McMahon T, Wang D, Hundle B, Aley KO, Isenberg W, McCarter G, Green PG, Hodge CW, Levine JD, Messing RO. A novel nociceptor signaling pathway revealed in protein kinase C epsilon mutant mice. Neuron. 1999; 24:253-260. [PubMed: 10677042]

Kim YH, Park CK, Back SK, Lee CJ, Hwang SJ, Bae YC, Na HS, Kim JS, Jung SJ, Oh SB. Membrane-delimited coupling of TRPV1 and mGluR5 on presynaptic terminals of nociceptive neurons. J Neurosci. 2009; 29:10000-10009. [PubMed: 19675234]

Lea PM 4th, Faden AI. Modulation of metabotropic glutamate receptors as potential treatment for acute and chronic neurodegenerative disorders. Drug News Perspect. 2003; 16:513-522. [PubMed: 14668949]

Lee JS, Ro JY. Peripheral metabotropic glutamate receptor 5 mediates mechanical hypersensitivity in craniofacial muscle via protein kinase C dependent mechanisms. Neuroscience. 2007; 146:375383. [PubMed: 17306466]

Lee KE, Davis MB, Mejilla RM, Winkelstein BA. In vivo cervical facet capsule distraction: mechanical implications for whiplash and neck pain. Stapp Car Crash J. 2004a; 48:373-396. [PubMed: 17230274]

Lee KE, Davis MB, Winkelstein BA. Capsular ligament involvement in the development of mechanical hyperalgesia after facet joint loading: behavioral and inflammatory outcomes in a rodent model of pain. J Neurotrauma. 2008; 25:1383-1393. [PubMed: 19061382]

Lee KE, Franklin AN, Davis MB, Winkelstein BA. Tensile cervical facet capsule ligament mechanics: failure and subfailure responses in the rodent. J Biomech. 2006; 39:1256-1264. [PubMed: 15899488]

Lee KE, Thinnes JH, Gokhin DS, Winkelstein BA. A novel rodent neck pain model of facet-mediated behavioral hypersensitivity: Implications for persistent pain and whiplash injury. J Neurosci Methods. 2004b; 137:151-159. [PubMed: 15262055]

Leng S, Mizumura K, Koda K, Kumasawa T. Excitation and sensitization of the heat response induced by a phorbol ester in canine visceral polymodal receptors studied in vitro. Neurosci Lett. 1996; 206:13-19. [PubMed: 8848270]

Li W, Neugebauer V. Differential roles of mGluR1 and mGluR5 in brief and prolonged nociceptive processing in central amygdala neurons. J Neurophysiol. 2004; 91:13-24. [PubMed: 13679408]

Liu D, Thangnipon W, McAdoo DJ. Excitatory amino acids rise to toxic levels upon impact injury to the rat spinal cord. Brain Res. 1991; 547:344-348. [PubMed: 1884213]

Lu Y, Chen C, Kallakuri S, Patwardhan A, Cavanaugh JM. Neurophysiological and biomechanical characterization of goat cervical facet joint capsules. J Orthop Res. 2005; 23:779-787. [PubMed: 16022990]

Luan F, Yang KH, Deng B, Begeman PC, Tashman S, King AI. Qualitative analysis of neck kinematics during low-speed rear-end impact. Clin Biomech. 2000; 15:649-657.

McAdoo DJ, Xu GY, Robak G, Hughes MG. Changes in amino acid concentrations over time and space around an impact injury and their diffusion through the rat spinal cord. Exp Neurol. 1999; 159:538-544. [PubMed: 10506525]

Mense S, Prabhakar NR. Spinal termination of nociceptive afferent fibres from deep tissues in the cat. Neurosci Lett. 1986; 66:169-174. [PubMed: 3725183] 
Mills CD, Xu GY, McAdoo DJ, Hulsebosch CE. Involvement of metabotropic glutamate receptors in excitatory amino acid and GABA release following spinal cord injury in rat. J Neurochem. 2001; 79:835-848. [PubMed: 11723176]

Miralles VJ, Martinez-Lopez I, Zaragoza R, Borras E, Garcia C, Pallardo FV, Vina JR. Na+ dependent glutamate transporters (EAAT1, EAAT2, and EAAT3) in primary astrocyte cultures: effect of oxidative stress. Brain Res. 2001; 922:21-29. [PubMed: 11730698]

Panjabi MM, Cholewicki J, Nibu K, Babat LB, Dvorak J. Simulation of whiplash trauma using whole cervical spine specimens. Spine. 1998; 23:17-24. [PubMed: 9460147]

Pearson A, Ivancic PC, Ito S, Panjabi MM. Facet joint kinematics and injury Mechanisms during simulated whiplash. Spine. 2004; 29:390-397. [PubMed: 15094535]

Pickar JG, McLain RF. Responses of mechanosensitive afferents to manipulation of the lumbar facet in the cat. Spine. 1995; 20:2379-2385. [PubMed: 8578387]

Pin JP, Bockaert J. Get receptive to metabotropic glutamate receptors. Curr Opin Neurobiol. 1995; 5:342-349. [PubMed: 7580157]

Pitcher MH, Ribeiro-da-Silva A, Coderre TJ. Effects of inflammation on the ultrastructural localization of spinal cord dorsal horn group I metabotropic glutamate receptors. J Comp Neurol. 2007; 505:412-423. [PubMed: 17912745]

Quinn KP, Dong L, Golder FJ, Winkelstein BA. Neuronal hyperexcitability in the dorsal horn after painful facet joint injury. Pain. 2010; 151:414-421. [PubMed: 20739124]

Quinn KP, Lee KE, Ahaghotu CC, Winkelstein BA. Structural changes in the cervical facet capsular ligament: potential contributions to pain following subfailure loading. Stapp Car Crash J. 2007; 51:169-187. [PubMed: 18278597]

Rimaniol AC, Mialocq P, Clayette P, Dormont D, Gras G. Role of glutamate transporters in the regulation of glutathione levels in human macrophages. Am J Physiol Cell Physiol. 2001; 281:C1964-1970. [PubMed: 11698255]

Rothman SM, Winkelstein BA. Chemical and mechanical nerve root insults induce differential behavioral sensitivity and glial activation that are enhanced in combination. Brain Res. 2007; 1181:30-43. [PubMed: 17920051]

Rothman SM, Winkelstein BA. Cytokine antagonism reduces pain and modulates spinal astrocytic reactivity after cervical nerve root model of radiculopathy. J Neurotrauma. 2010; 27:803-814. [PubMed: 20121422]

Rothstein JD, Dykes-Hoberg M, Pardo CA, Bristol LA, Jin L, Kuncl RW, Kanai Y, Hediger MA, Wang Y, Schielke JP, Welty DF. Knockout of glutamate transporters reveals a major role for astroglial transport in excitotoxicity and clearance of glutamate. Neuron. 1996; 16:675-686. [PubMed: 8785064]

Rothstein JD, Martin L, Levey AI, Dykes-Hoberg M, Jin L, Wu D, Nash N, Kuncl RW. Localization of neuronal and glial glutamate transporters. Neuron. 1994; 13:713-725. [PubMed: 7917301]

Schaible HG, Ebersberger A, Von Banchet GS. Mechanisms of pain in arthritis. Ann N Y Acad Sci 2002. 2002; 966:343-354.

Schepelmann K, Meblinger K, Schmidt RF. The effects of phorbol ester on slowly conducting afferents of the cat's knee joint. Exp Brain Res. 1993; 92:391-398. [PubMed: 8384119]

Schoepp DD, Jane DE, Monn JA. Pharmacological agents acting at subtypes of metabotropic glutamate receptors. Neuropharmacology. 1999; 38:1431-1476. [PubMed: 10530808]

Shashidharan P, Huntley GW, Murray JM, Buku A, Moran T, Walsh MJ, Morrison JH, Plaitakis A. Immunohistochemical localization of the neuron-specific glutamate transporter EAAC1 (EAAT3) in rat brain and spinal cord revealed by a novel monoclonal antibody. Brain Res. 1997; 773:139148. [PubMed: 9409715]

Sluka KA, Westlund KN. Behavioral and immunohistochemical changes in an experimental arthritis model in rats. Pain. 1993; 55:367-377. [PubMed: 7510059]

Souza AL, Moreira FA, Almeida KR, Bertollo CM, Costa KA, Coelho MM. In vivo evidence for a role of protein kinase $\mathrm{C}$ in peripheral nociceptive processing. Br J Pharmacol. 2002; 135:239-247. [PubMed: 11786500] 
Stemper BD, Yoganandan N, Gennarelli TA, Pintar FA. Localized cervical facet joint kinematics under physiological and whiplash loading. J Neurosurg Spine. 2005; 3:471-476. [PubMed: 16381210]

Sundararajan S, Prasad P, Demetropoulos CK, Tashman S, Begeman PC, Yang KH, King AI. Effect of head-neck position on cervical facet stretch of post mortem human subjects during low speed rear end impacts. Stapp Car Crash J. 2004; 48:331-372. [PubMed: 17230273]

Sung B, Lim G, Mao J. Altered expression and uptake activity of spinal glutamate transporters after nerve injury contribute to the pathogenesis of neuropathic pain in rats. J Neurosci. 2003; 23:2899_ 2910. [PubMed: 12684477]

Sweitzer SM, Wong SM, Peters MC, Mochly-Rosen D, Yeomans DC, Kendig JJ. Protein kinase C epsilon and gamma: involvement in formalin-induced nociception in neonatal rats. J Pharmacol Exp Ther. 2004; 309:616-625. [PubMed: 14762097]

Todd AJ. Anatomy of primary afferents and projection neurons in the rat spinal dorsal horn with particular emphasis on substance P and the neurokinin 1 receptor. Exp Physiol. 2002; 87:245-249. [PubMed: 11856970]

Valtschanoff JG, Phend KD, Bernardi PS, Weinberg RJ, Rustioni A. Amino acid immunocytochemistry of primary afferent terminals in the rat dorsal horn. J Comp Neurol. 1994; 346:237-252. [PubMed: 7525664]

Vera-Portocarrero LP, Mills CD, Ye Z, Fullwood SD, McAdoo DJ, Hulsebosch CE, Westlund KN. Rapid changes in expression of glutamate transporters after spinal cord injury. Brain Res. 2002; 927:104-110. [PubMed: 11814437]

Walker K, Bowes M, Panesar M, Davis A, Gentry C, Kesingland A, Gasparini F, Spooren W, Stoehr N, Pagano A, Flor PJ, Vranesic I, Lingenhoehl K, Johnson EC, Varney M, Urban L, Kuhn R. Metabotropic glutamate receptor subtype 5 (mGlu5) and nociceptive function. I Selective blockade of mGlu5 receptors in models of acute, persistent and chronic pain. Neuropharmacology. 2001; 40:1-9. [PubMed: 11077065]

Wang S, Lim G, Yang L, Sung B, Mao J. Downregulation of spinal glutamate transporter EAAC1 following nerve injury is regulated by central glucocorticoid receptors in rats. Pain. 2006; 120:7885. [PubMed: 16360273]

Wang YJ, Tseng GF. Spinal axonal injury transiently elevates the level of metabotropic glutamate receptor 5, but not 1, in cord-projection central neurons. J Neurotrauma. 2004; 21:479-489. [PubMed: 15115597]

Weisshaar CL, Dong L, Bowman AS, Perez FM, Guarino BB, Sweitzer SM, Winkelstein BA. Metabotropic glutamate receptor-5 and protein kinase C-epsilon increase in dorsal root ganglion neurons and spinal glial activation in an adolescent rat model of painful neck injury. $\mathrm{J}$ Neurotrauma. 2010; 27:2261-2271. [PubMed: 20925479]

Xu T, Jiang W, Du D, Xu Y, Hu Q, Shen Q. Role of spinal metabotropic glutamate receptor subtype 5 in the development of tolerance to morphine-induced antinociception in rat. Neurosci Lett. 2007; 420:155-159. [PubMed: 17512115]

Yoganandan N, Pintar FA, Cusick JF. Biomechanical analyses of whiplash injuries using an experimental model. Accid Anal Prev. 2002; 34:663-671. [PubMed: 12214961]

Yoganandan N, Pintar FA, Klienberger M. Cervical spine vertebral and facet joint kinematics under whiplash. J Biomech Eng. 1998; 120:305-307. [PubMed: 10412396]

Zhang H, Xin W, Dougherty PM. Synaptically evoked glutamate transporter currents in spinal dorsal horn astrocytes. Mol Pain. 2009; 5:36. [PubMed: 19570219]

Zimmermann M. Ethical guidelines for investigations of experimental pain in conscious animals. Pain. 1983; 16:109-110. [PubMed: 6877845] 


\section{Highlights}

- Painful facet joint loading elevates mGluR5 and PKCe expression in DRG neurons.

- Increases in mGluR5 and PKC $\varepsilon$ at day 7 are localized to small neurons in the DRG.

- Spinal neuronal mGluR5 increases at day 7 after facet joint distraction.

- Spinal PKCe is not modulated after a painful joint injury.

- Spinal EAAC1 is increased only the joint injury conditions that are not associated with joint pain. 
(A)

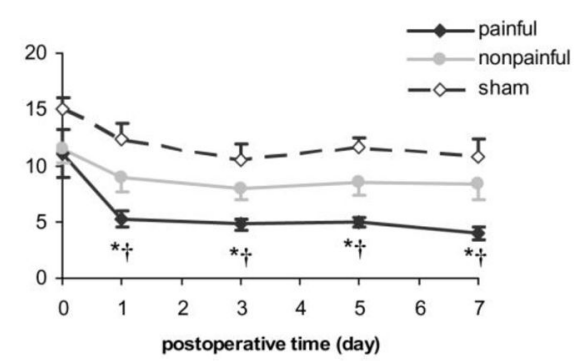

(B)

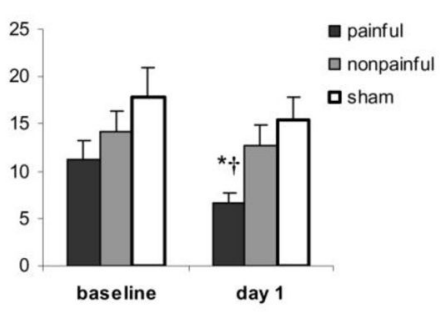

Fig. 1. Forepaw mechanical hyperalgesia as measured by the average threshold response to von Frey filament stimulation

(A) Painful distraction significantly reduced thresholds below those of nonpainful $(* \mathrm{p}<0.02)$ and sham $(\dagger \mathrm{p}<0.001)$ for all post-surgical testing days. (B) In separate groups of rats, mechanical hyperalgesia was significantly reduced at day 1 after painful distraction compared to both nonpainful $(* \mathrm{p}<0.002)$ and sham $(\dagger \mathrm{p}<0.001)$ controls. Data shown are average with the standard error of the mean. 


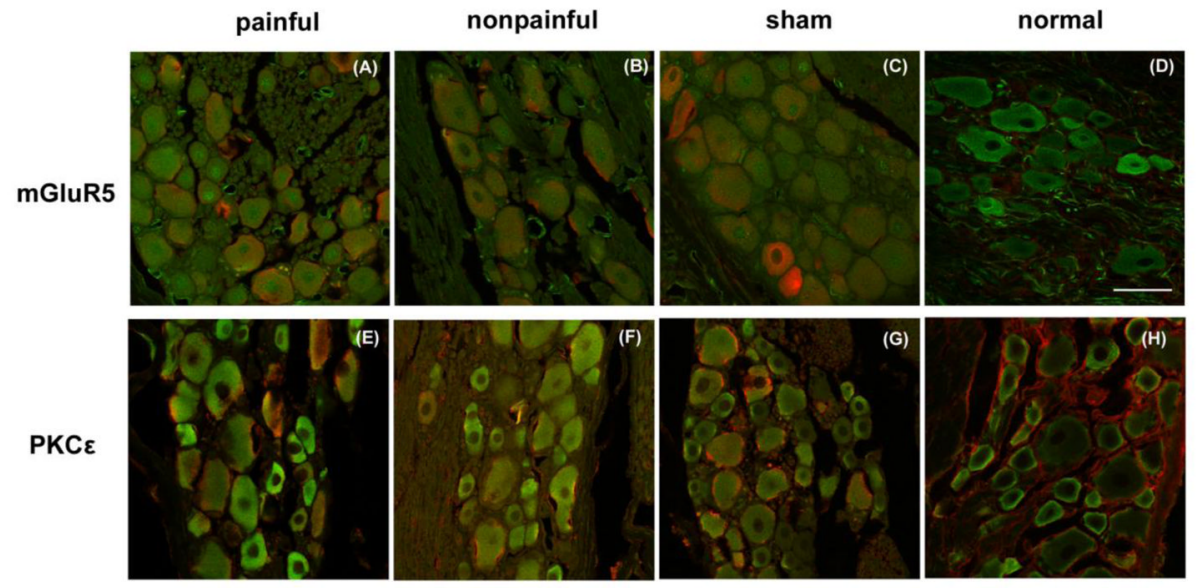

(I)

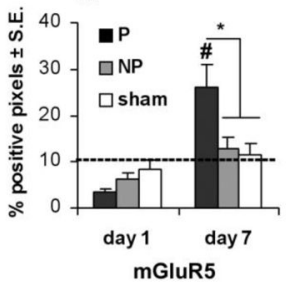

(J)
(K)
(L)
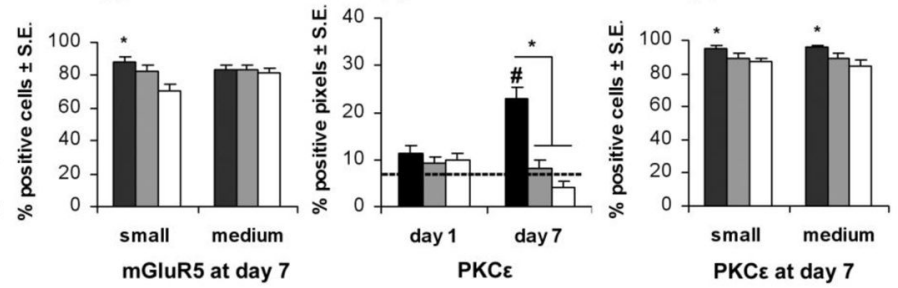

Fig. 2. Neuronal expression of mGluR5 and PKC $\varepsilon$ in the DRG

Representative images from day 7 showing the colocalization of (A-D) mGluR5 (green) or (E-H) PKC $\varepsilon$ (green) with neurons (MAP2; red) in the DRG. (I) Quantification of mGluR5 expression after painful distraction $(\mathrm{P})$ was significantly elevated $(* \mathrm{p} \leq 0.012)$ above nonpainful (NP), sham and normal groups at day 7 , and was significantly increased $(\# p<0.001)$ over day 1 levels. (J) The percentage of small-diameter neurons expressing mGluR5 after painful distraction was significantly increased (* $\mathrm{p}=0.013)$ over sham at day 7 . (K) Similarly, neuronal expression of PKC $\varepsilon$ was significantly increased (*p<0.001) only after the painful distraction at day 7; (L) this elevation was specific to both small- and medium-diameter neurons and was only significant $(\mathrm{p}<0.03)$ when comparing painful to sham. The dashed line indicates the normal levels in $(\mathbf{I}, \mathbf{K})$. 

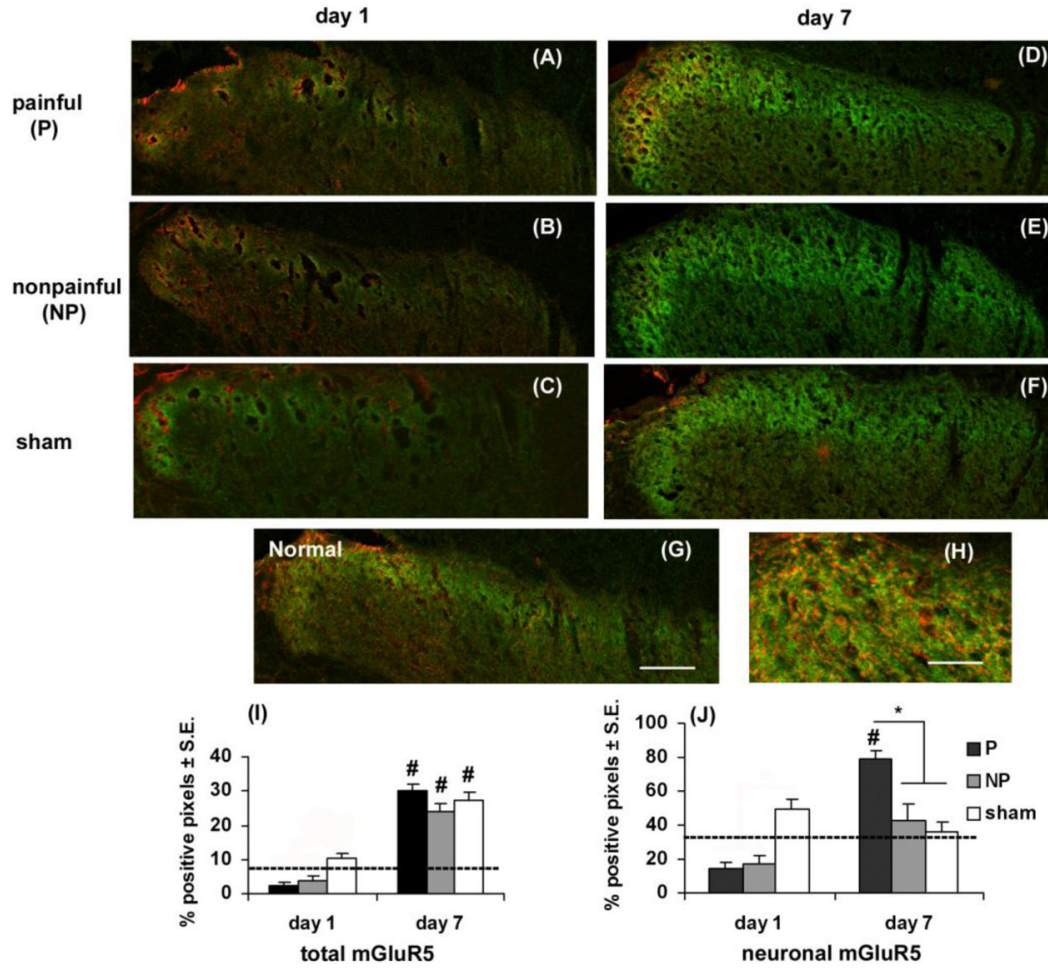

neuronal mGluR5
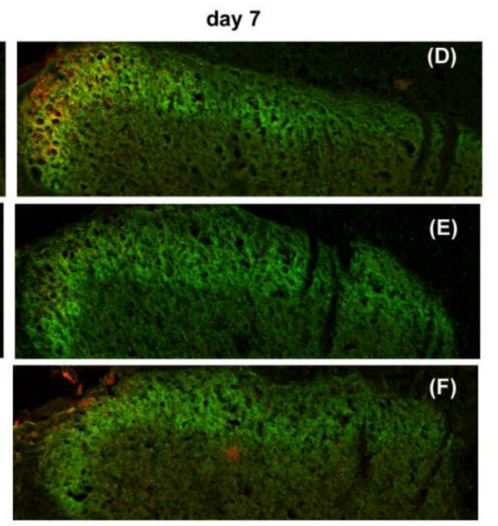

(G)

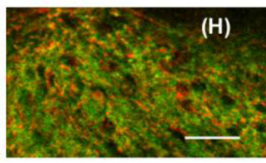

Fig. 3. Spinal mGluR5 expression in the dorsal horn

Representative images of mGluR5 (green) and neurons (MAP2; red) in the spinal dorsal horn at (A-C) day 1 and (D-F) day 7 after joint distraction. A higher magnification image shows the co-localization of mGluR5 and MAP2 in (H). Scale bar is $100 \mu \mathrm{m}$ in $(\mathbf{G})$ (applies to $\mathbf{A}-\mathbf{F})$, and $20 \mu \mathrm{m}$ in $(\mathbf{H})$. Quantification of (I) total and (J) neuronal mGluR5 expression shows no differences between groups at day 1. (J) Neuronal mGluR5 expression was significantly increased $(* \mathrm{p} \leq 0.05)$ after painful distraction over nonpainful and sham at day 7. The pound sign $(\#)$ indicates a significant $(\mathrm{p}<0.001)$ increase at day 7 compared to day 1 as indicated for a group. The dashed line indicates the normal levels in (I,J). 


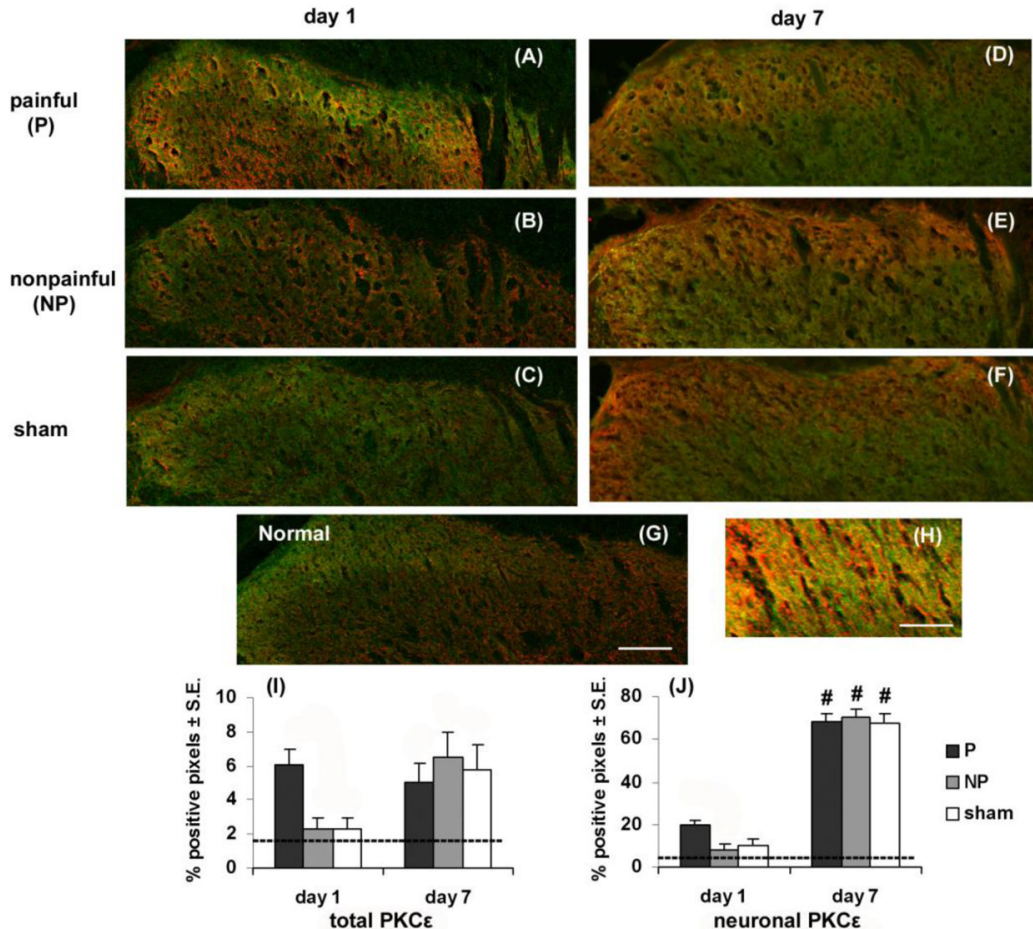

Fig. 4. Spinal PKC $\varepsilon$ expression after distractions

Representative images of $\mathrm{PKC} \varepsilon$ (green) co-labeled with MAP2 (red) in the spinal dorsal horn at (A-C) day 1 and (D-F) day 7. A close-up image showing the co-localization of PKC $\varepsilon$ and MAP2 is shown in (H). Scale bar is $100 \mu \mathrm{m}$ in (G) (applies to A-F) and $20 \mu \mathrm{m}$ in (H). (I) There was no difference in total $\mathrm{PKC} \varepsilon$ expression between any group or compared to normal. (J) Neuronal PKC $\varepsilon$ expression in all groups was significantly elevated $(\# \mathrm{p}<0.001)$ above their corresponding levels at day 1 and normal levels; there was no difference between any groups at day 7 . The dashed line in $(\mathbf{I}, \mathbf{J})$ indicates the normal expression levels. 

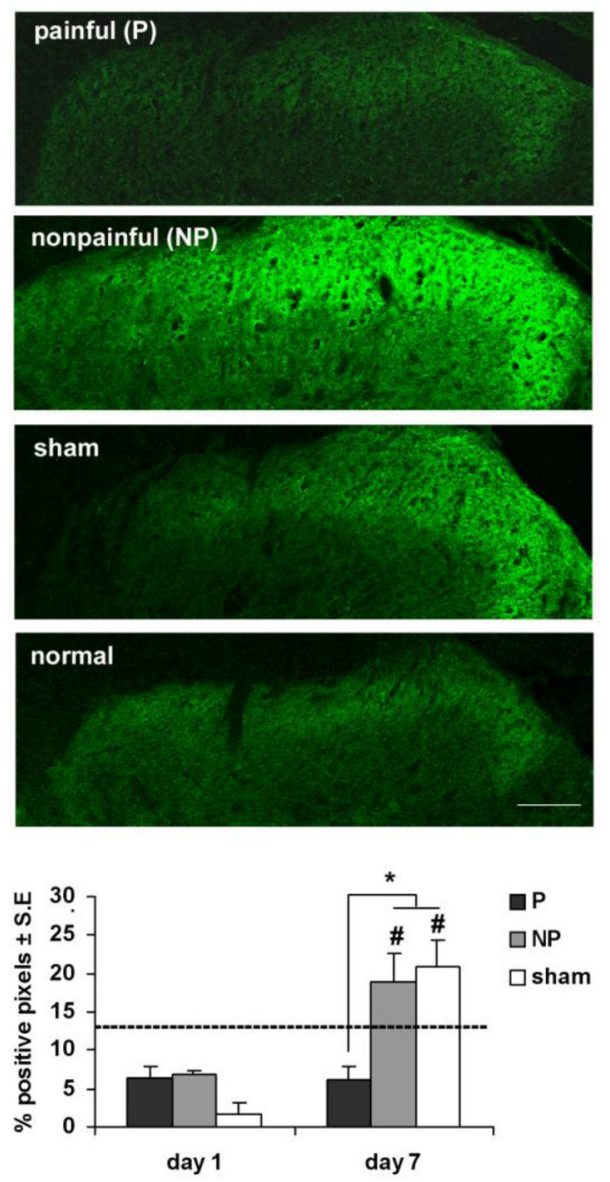

Fig. 5. Spinal EAAC1 expression

Representative images of EAAC1 expression in the spinal cord at day 7 are shown. EAAC1 was unchanged after painful distraction at both days 1 and 7. Yet, EAAC1 expression after nonpainful and sham was significantly increased at day 7 compared to day 1 (\#p $\leq 0.02$ ) and both groups exhibited greater expression than in the painful group $(* \mathrm{p}<0.03)$. The dashed line indicates the normal level. 


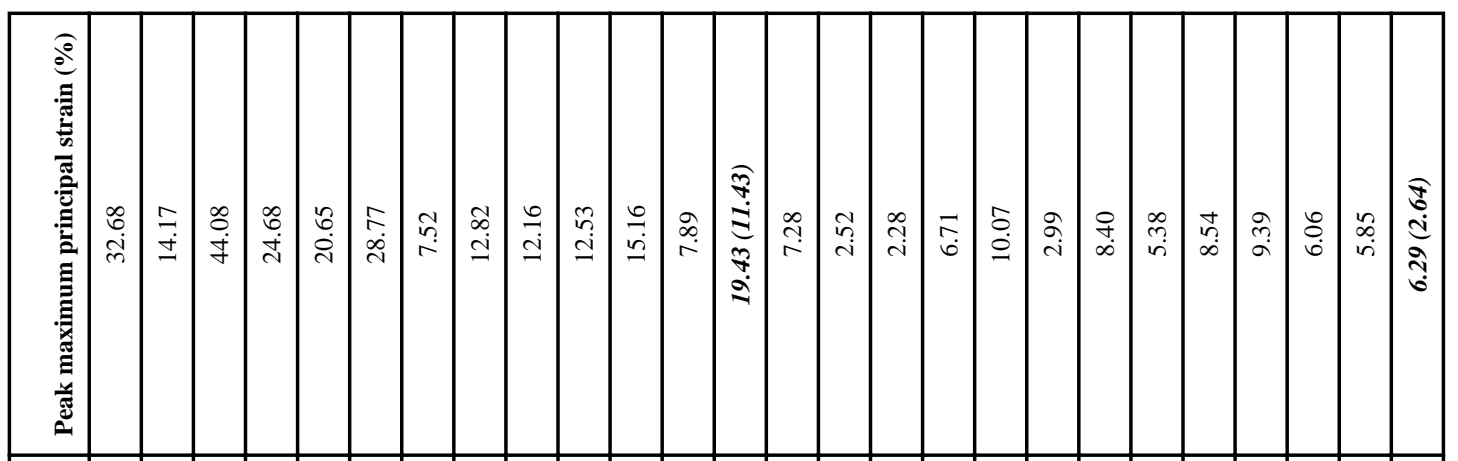

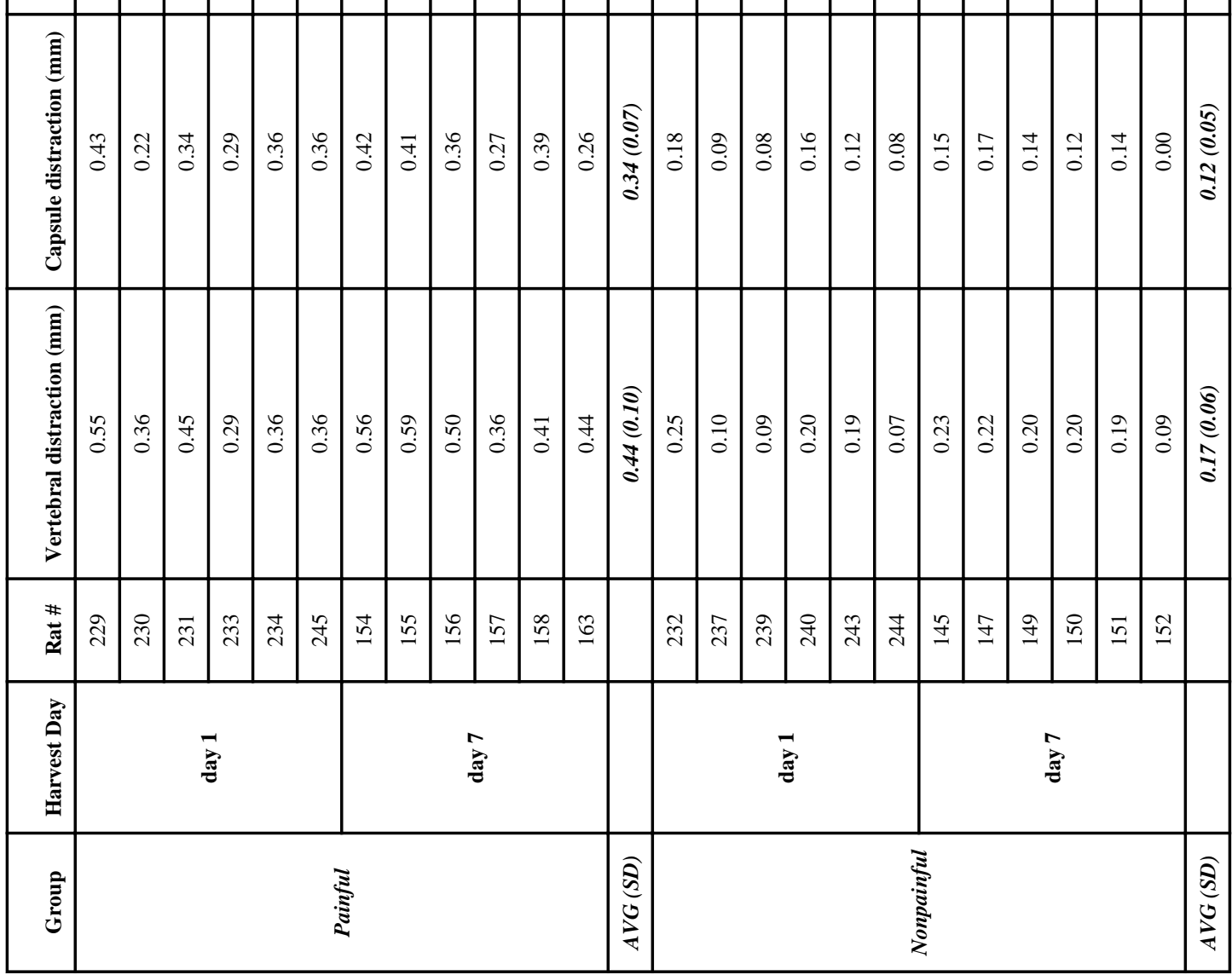




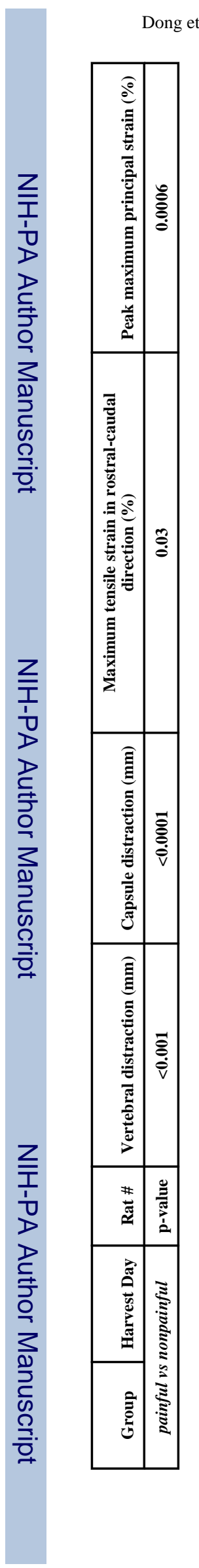

Page 23

Brain Res. Author manuscript; available in PMC 2013 June 21. 